ТЕОРЕТИЧЕСКИ ВОЗМОЖНАЯ И ПРАКТИЧЕСКИ РЕАЛИЗУЕМАЯ ПО УСЛОВИЯМ ВЛАГООБЕСПЕЧЕННОСТИ И ЗАСОЛЕННОСТИ ПРОДУКТИВНОСТЬ СВЕТЛО-КАШТАНОВОЙ ПОЧВЫ СЕВЕРО-ЗАПАДНОГО ПРИКАСПИЯ (НА ПРИМЕРЕ КОЧУБЕЙСКОЙ БИОСФЕРНОЙ СТАНЦИИ ПИБР ДНЦ РАН)

\title{
THEORETICALLY POSSIBLE AND PRACTICALLY RELIZABLE PRODUCTIVITY OF THE LIGHT-CHESTNUT SOILS OF THE NORTHERN WEST PRECASPIAN REGION ACORDING TO THE MOISTURE AND SOLINITY (ON EXAMPLE OF KOCHUBEY BIOSPHERE STATION OF PIBR DNC RAS)
}

\author{
Г.Н. Гасанов ${ }^{1}$, Т.А. Асварова' ${ }^{1}$ К.М. Гаджиевㄹ, 3.Н. Ахмедова', \\ А.С. Абдулаева' 1 , Р.P. Баширов ${ }^{1}$, М.С. Султанахмедов" \\ G.N. Hasanov', T.A. Asvarova2', K.M. Gadzhiev'1, Z.N. Akhmedova1, \\ A.S. Abdulaeva1, R.R. Bashirov', M.S. Sultanakhmedov² \\ 1Прикаспийский институт биологических ресурсов ДНЦ РАН, \\ ул. М. Гаджиева, 45, Махачкала 367025 Россия \\ 2Дагестанский научный центр РАН, \\ отдел математики и инсорматики, \\ ул. М. Гаджиева, 45, Махачкала 367025 Россия \\ Precaspian Institute of Biological Resources \\ of Dagestan Scientific Center of Russian Academy of Sciences, \\ Gadzhiev str., 45, Makhachkala 367025 Russia \\ 2Dagestan Scientific Center of the Russian Academy of Sciences, \\ Department of Mathematics and Computer Science, \\ Gadzhiev str., 45, Makhachkala 367025 Russia
}

Резюме. В статье приведены данные по урожайности, видовому составу фитоценозов и коэффициентам использования ФАР в зависимости от интегралов засушливости и увлажненности климата, испаряемости, коэффициента увлажнения и динамики вредных солей в почве по годам и сезонам года.

Abstract. The article presents the productivity data, the species composition and utilization rates phytocenoses FAR depending on theintegrals of dryness and moisture climate volatility, coefficient of moisture and dynamics of harmful salts in the soil according to years and seasons of the year.

Methods. The studies were conducted on light-chestnut carbonate saline soil of Kochubey biosphere stations on the territory of the Terek- Kuma Lowland Precaspianregion in 2011-2013. The calculation of the use of FAR was conducted using the formula A.A. Nichiporovich to determine the theoretically possible yield of plants. Klimatogrammy during these years has been compiled by the method Walter. Stocks above and below ground plant matter into account by the method of A.A.Titlyanova. The names of species given by S.K. Cherepanov.

Results. According to the results of our observations, the most important for achieving high productivity ephemeral synusia under these conditions include precipitation for April and May. Between the amount of rainfall in April and May and the productivity of abovegroundphytomass ofephemera direct correlation exists, which in 2011 had a strong, and in the next two years-the average severity. In 2012 the volatility increased, KU fell in 5 times. Such weather conditions contributed to the rise of water-soluble salts to the upper soil horizons and substantial change in species composition phytocenoses. The content $\mathrm{Cl}^{-}$in the layer 0-20 cm over the same period 2011 increased in 3.9 times, $\mathrm{SO}_{4}^{--}-1.7$ in times. If in 2011 the stepen soil salinity in the layer 0-35 cm characterized as weak, in 2012 the average at the same chloride- sulphate type of salinity. Obviously , an increase in the content of $\mathrm{Cl}^{-}$- ions and its relationship to the $\mathrm{SO}_{4}^{--}$contributed to a dramatic increase in productivity and thistle herbs in 2012. Luxuriant growth of Salsola iberica Sennen et Pau particularly stood. Thus, the formation of a biomass and species composition in the Terek-Kuma Lowland Precaspian is the result of the cumulative effects of different environmental factors, the main ones are: precipitation, air temperature, its relative humidity, evaporation, moisture ratio and the degree of soil salinity and chemistry. These dependencies are expressed by the following multiple regression equation. Depending on climatic conditions, the pasture use phytocoenoses $0,20-0,57 \%$ FAR. Win ephemera and ephemeroids of this amount is an average over years of research about $20 \%$, the remaining $80 \%$-grasses and thistle, the majority of which occur in Salsola iberica Sennen et Pau, bad eating animals and less valuable as fodder representative thistle.

Main conclusion. Our results suggest that, in the context of the Terek-Kuma Lowland there are two peaks of productivity of phytocenoses: first one of ephemeras andephemeroids is in mid-May to early July, the second one of grasses and thistleis in the second half of September. The main factors to achieve high productivity ephemeras and ephemeroids on light-chestnut soil of the North- West Precaspian are about $80-85 \mathrm{~mm}$ rainfall during April - May, with average daily air temperature $15-16^{\circ} \mathrm{C}$, its relative humidity $70-73 \%$, volatility of $130-140 \mathrm{~mm}$, KU 0.30, chloride-sulphate type of salinity in the layer of a low degree of 0 
$35 \mathrm{~cm}$. In years with heavy rainfall in July and August $(102 \mathrm{~mm})$, despite an increase in average daily air temperature to $25-26{ }^{\circ} \mathrm{C}$ and volatility to $275 \mathrm{~mm}$, a relatively high $\mathrm{KU}(0.21)$, the content of Clin the layer $0-20 \mathrm{~cm}$ reduced $1,40 \mathrm{mg}$-ekv. $/ 100 \mathrm{~g}$, ratio $\mathrm{Cl}^{-}$ : $\mathrm{SO}_{4}^{--}$to $0,59-0,84$ and productivity grasses and Salsola iberica Sennen et Pauincreased. The FAR utilization reaches 0.57 , of which the biomass of grasses and Salsola iberica Sennenet Pau falls $87.6 \%$ (2012).The task of future research is to determine its phitomeliorative role: removal of salt-forming ions from the soil and itsfurther redistribution in ecosystem, considering the nature of movement on the territory of Salsola iberica Sennen et Pau.

Ключевые слова: гидротермические условия, солеобразующие ионы, засоленность почвы, видовой состав фитоценоза, надземная фитомасса, подземная фитомасса, коэффициент использования ФАР.

Key words: hydrothermal conditions, salt-forming ions, salinity, species composition ofphytocenosis, aboveground phytomass, underground phytomass, coefficient the use of FAR.

\section{ВВЕДЕНИЕ}

Возможность достижения определенного уровня урожайности фитоценозов зависит от многочисленных космических и почвенных факторов. Основным космическим фактором, регулирующим продуктивность почв, является поступающая на ее поверхность фотосинтетически активная радиация (ФАР). Ее величина колеблется в значительных пределах в зависимости от географической широты и гипсометрических отметок местности. Так, на $1 \mathrm{~cm}^{2}$ поверхности почвы в районе Санкт-Петербурга приходится 34,6 ккал, Москвы - 44,4, Самары - 51,2, Астрахани и Махачкалы - 53,4-53,5 ккал. (Каюмов, 1977). В предгорной подпровинции Дагестана на такую же площадь поступает 47,55 (Буйнакск) - 43,91 (Сергокала) ккал, в терско-сулакской подпровинции - 49,94 (Бабаюрт) - 51,19 (Кизляр), в терско-кумской подпровинции (Кочубей) - 50,87, в приморской низменности (Дербент) - 56,87 ккал (Гасанов, 2008). Эти показатели являются определяющими при расчетах теоретически возможной урожайности фитоценозов.

Однако фактически достигаемая урожайность фитомассы в экосистемах зависит от того, как складываются климатические условия конкретного года или периода (количество и интенсивность осадков, температура и относительная влажность воздуха и др.) и от почвенных условий (водно-физических характеристик, обеспеченности питательными элементами, степени и типа засоленности и др.). Так, для формирования урожайности $3-$ 4 т зерна с 1 га даже в агроценозах, условия функционирования которых регулируются в значительной степени, используется не более 1,5-2 \% ФАР (Гасанов, 2008). Незначительное количество ее используется и в условиях рассматриваемой нами территории, где урожайность воздушно-сухой надземной фитомассы очень низкая. В зависимости от режима использования пастбищ она может колебаться от 1,6 до 4,4 ц/га (Муратчаева, Хабибов, 2008), от стадии развития процесса опустынивания - от 1-3 до 5-6 ц/га (Залибеков, $2000)$, от почвенных разностей даже одного и того же типа - от $5,2-5,4$ ц/га (светлокаштановая солончаковатая) до 7,2-8,1 ц/га (светло-каштановая солонцеватая) (Усманов, 2009). На прилегающей к Терско-Кумской низменности территории Ергененской возвышенности и Прикаспийской низменности Республики Калмыкия, в зависимости от состава растительных ассоциаций, урожайность фитоценозов отклоняется в пределах от 1,4 до 17,1 ц/га (Джапова, 2007). По нашим расчетам, при урожайности 5 ц/га воздушно-сухой фитомассы из поступающей на поверхность почвы 50,0 ккал/см² пастбищный фитоценоз использует всего $0,04 \%$ ФАР. В этой связи чрезвычайный интерес в научном и практическом плане представляет исследование фактически достигаемой урожайности фитоценозов при различных условиях влагообеспеченности территории не только по среднегодовым показателям, но и по сезонам года, а также с учетом динамики токсичных солей и их химизма по горизонтам почвы в Северо-Западном Прикаспии. Такие исследования в рассматриваемых и сопредельных регионах Прикаспия ранее не проводились.

\section{ОБЪЕКТ И МЕТОДИКА ИССЛЕДОВАНИЙ}

Исследования проводились на светло-каштановой карбонатной солончаковой почве Кочубейской биосферной станции на территории Терско-Кумской низменности

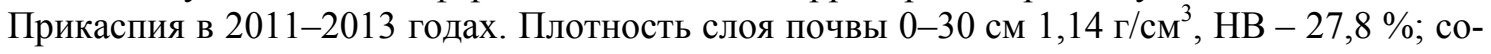


держание гумуса - 1,12 \%, $\mathrm{P}_{2} \mathrm{O}_{5}-1,11$ мг/100 г, $\mathrm{K}_{2} \mathrm{O}-20,12$ мг/100 г почвы. Тип засоления (по слоям) сульфатно-хлоридный и хлоридно-сульфатный, степень засоления - от слабого в верхних слоях до сильного в ниже лежащих.

В условиях рассматриваемой низменности на $1 \mathrm{~cm}^{2}$ почвы за год поступает 50,87 ккал $(213,23$ КДж) ФАР, в том числе по месяцам (ккал): январь - 0,59, февраль 1,99 , март - 3,82, апрель - 5,97, май - 7,27, июнь - 8,48, июль - 7,84, август - 6,22, сентябрь - 4,59, октябрь - 2,57, ноябрь - 1,19, декабрь - 0,34 (Гасанов и др., 2004). Продолжительность вегетационного периода растений рассчитывалась, исходя из среднесуточной температуры воздуха, превышающей $5{ }^{\circ} \mathrm{C}$.

Расчет коэффициента использования ФАР проводился с использованием формулы Ничипоровича (1963) для определения теоретически возможной урожайности растений:

$$
\mathrm{Y}=\mathrm{R} \times 10^{8} \times \mathrm{K} / 10^{2} \times 4 \times 10^{3} \times 10^{2} \text {, где }
$$

У - биологический урожай абсолютно сухой надземной массы, ц/га;

$\mathrm{R} \times 10^{8}$ - количество ФАР, поступающей на 1 га за период вегетации растений, ккал; К - запланированный коэффициент использования ФАР, \%;

$4 \times 10^{3}-$ количество энергии, выделяемой при сжигании 1 кг сухого вещества биомассы, ккал/кг;

$10^{2}$ - перевод кг в $и$ продукции.

Для расчета коэффициента использования ФАР формула имеет вид:

$$
\mathrm{K}=\mathrm{y} \times 10^{2} \times 4 \times 10^{3} \times 10^{2} / \mathrm{R} \times 10^{8} .
$$

Климатограммы за эти годы нами составлены по методу Вальтера (Walter, 1964), в них в засушливые периоды кривая температур воздуха располагается над кривой осадков, во влажные, наоборот, кривая осадков размещается выше кривой температур. Для вычисления площадей участков между линиями среднемесячных температур воздуха $\left({ }^{\circ} \mathrm{C}\right)$ и суммы месячных осадков (мм) использованы интегралы:

$$
\begin{aligned}
& \int_{a}^{2} \max (T(t)-W(t), 0) d t-\text { для вычисления площади засушливых периодов, } \\
& \int_{a}^{2} \max (W(t)-T(t), 0) d t-\text { для увлажненных периодов. }
\end{aligned}
$$

Запасы надземного и подземного растительного вещества учитывались по методике Титляновой (1988). Надземную массу определяли укосным методом, с выделением фракций: живая фитомасса, ветошь (мертвые части растений, сохранившие связь с растениями), степной войлок (мертвые остатки растений на поверхности почвы, лишенные связи с растениями). Подземную массу определяли в эти же сроки на тех же учетных площадках после скашивания надземной массы до глубины 60 см методом монолита. Размер монолитов $10 \times 10 \times 10$ см, повторность 4-кратная. Названия видов растений даны по Черепанову (1981).

\section{РЕЗУЛЬТАТЫ ИССЛЕДОВАНИЙ}

Климатические условия в Терско-Кумской низменности за годы наших исследований сложились более благоприятно по сравнению с многолетними данными. Основным показателем, характеризующим наличие таких условий, является количество осадков, выпавших за вегетационный период фитоценозов. В 2011-2013 годах их выпало на 1531 мм больше, но температура воздуха за этот же период оказалась выше на $1-2,3^{\circ} \mathrm{C}$ по сравнению с многолетними данными. Очевидно, по этой причине испаряемость за годы исследований увеличилась на 10,8-22,1 \%. Если исходить из показателя КУ, то в 2012 и 2013 годах он соответствовал многолетнему значению $-0,11$ (отклонения $\pm 0,01$ ), а в 
2011 году превысил его на 0,03 . Поэтому можно считать, что годы проведения исследований в целом были типичными для условий Терско-Кумской низменности.

Однако количество осадков в разные периоды вегетации пастбищных фитоценозов было различным. Согласно результатам наших наблюдений, наиболее значимыми для достижения высокой продуктивности эфемеровой синузии в рассматриваемых условиях являются осадки за апрель и май. Температура воздуха за эти месяцы также благоприятствует формированию фитомассы растений. Соответственно по месяцам она составила: в 2011 году 9,2 и $18,4{ }^{\circ} \mathrm{C}$, в $2012-15,1$ и $20,9{ }^{\circ} \mathrm{C}$, в $2013-12,2$ и $20,0^{\circ} \mathrm{C}$. За указанные месяцы в 2011 году выпало 85 мм осадков, в $2012-25,3$ мм, в $2013-40$ мм, то есть в первый год исследований сумма осадков превысила показатели двух последующих лет в 3,4 и 2,1 раза. Между суммой осадков за апрель - май и урожайностью надземной фитомассы эфемеров существует прямая коррелятивная связь, которая в 2011 году имела сильную $(\mathrm{r}=0,89)$, а в два последующих года среднюю $(\mathrm{r}=0,43$ и 0,35$)$ степень выраженности.

Интеграл увлажненности $\int_{a}^{2} \max (W(t)-T(t), 0) d t$ за те же месяцы в 2011 году составил 29,8. В 2012 и 2013 гох кривая увлажненности опускалась ниже кривой среднесуточных температур воздуха, поэтому формировался интеграл засушливости $\int_{\Omega}^{t} \max (T(t)-W(t), 0) d t-($ а нө увлажненности), который составил, соответственно по годам, 37,3 и 98,9. Разница в его показателях между первым и двумя последующими годами составила 67,1 (2012) и 128,7 (2013) и сказалась существенно на продуктивности эфемеровой синузии. Главным образом по этой причине урожайность живой надземной фитомассы последней за 2012-2013 годы снизилась по сравнению с 2011 годом соответственно в 9,2 и 1,5 раза (рис. 1).
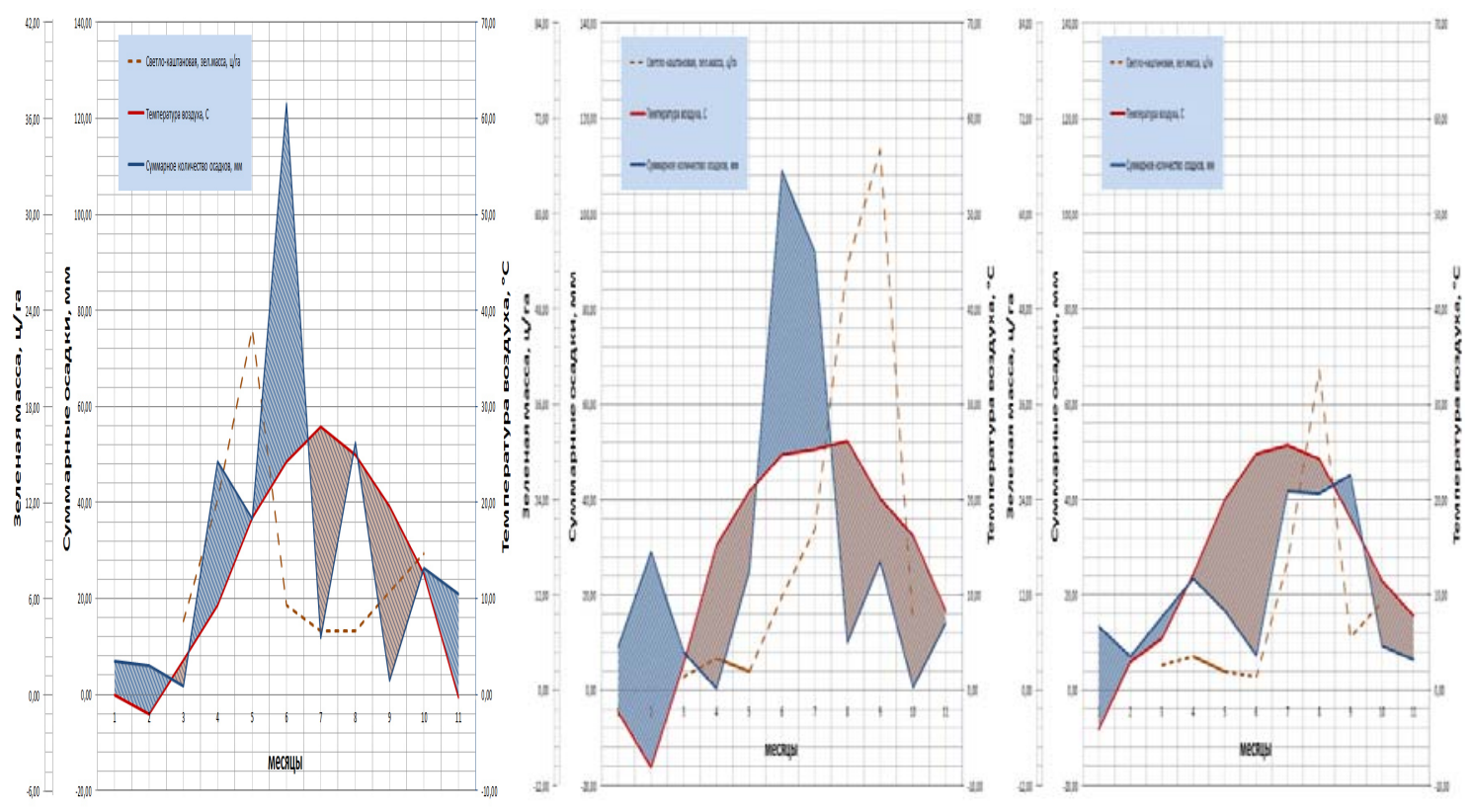

Рис. 1. Климатограммы и динамика накопления живой надземной фитомассы (в переводе на воздушно-сухую) по типам почв в 2011 (слева) и в 2012 (справа) годах. Синяя штриховка над красной линией - увлажненный период, желтая под красной линией - засушливый период.

Доминантами из эфемеровых на экспериментальном участке являются мятлик однолетний Poa aпnиa L., мятлик луковичный Poa bulbosa L., мортук восточный Eremopyrum orientale (L.) Jaub. et Spach., костер растопыренный Bromuss quarrosus L., костер кровельный Anisantha tectorum L., полевичка малая Eragrostic minor Host., из крестоцветных - бурачок пустынный Alussum desertorum Stapf. 
Осадки в первых двух декадах июня в 2011 году не обеспечили заметного прироста фитомассы. К этому времени урожай эфемеров уже был сформирован, и существенную прибавку к нему осадки этого периода не дали. А высокие температуры воздуха в течение этого и двух последующих месяцев (соответственно 24,3, 27,9 и $24.9^{\circ} \mathrm{C}$ ) способствовали интенсивной потере влаги выпавших осадков, поскольку испаряемость по тем же месяцам составила 291, 337 и 293 мм, КУ - соответственно 0,08, 0,04 и 0,18. Поэтому суммарный урожай разнотравья и солянок в последующие месяцы вегетации составил всего 8,9 ц/га - 67 \% к урожайности эфемеров и эфемероидов (рис. 2).
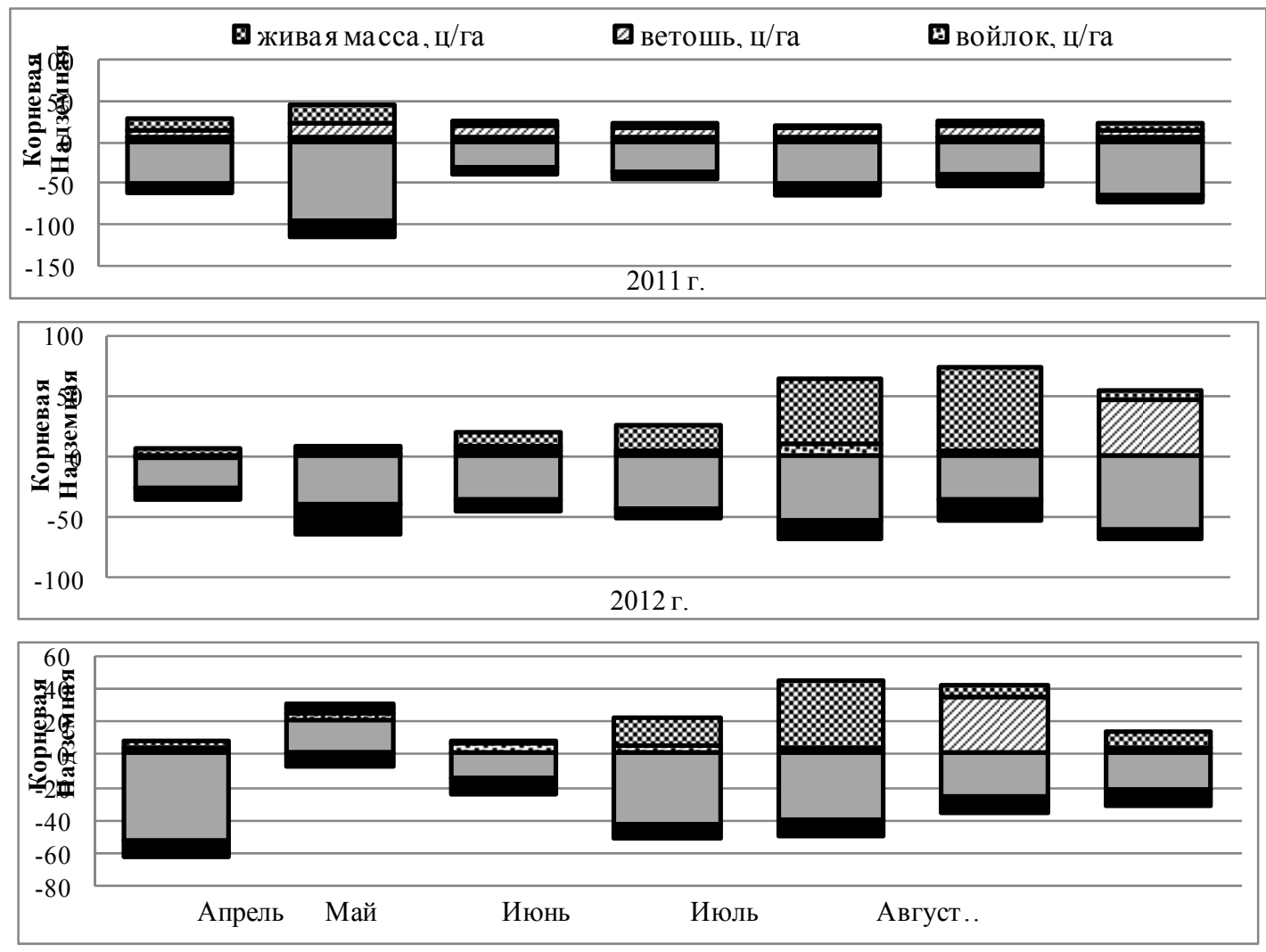

Рис. 2. Сезонная динамика накопления надземной и корневой массы растений в 2011-2013 годах, ц/га

В 2012 году интеграл засушливости составил 37,3, испаряемость увеличилась на 67 мм, КУ уменьшился в 5 раз (табл. 1). Такие метеорологические условия способствовали подъему водорастворимых солей к верхнему горизонту почвы и существенному изменению видового состава фитоценозов. Содержание $\mathrm{Cl}^{-}$в слое 0-20 см по сравнению с тем же периодом 2011 года увеличилось в 3,9 раза, $\mathrm{SO}_{4}$ - в 1,7 раза. В метровом слое сумма солеобразующего иона $\mathrm{Cl}^{-}$увеличилась в 2,2 раза, $\mathrm{SO}_{4}^{--}-$в 1,4 раза. Если в 2011 году степень засоленности почвы в слое 0-35 см характеризовалась как слабая (по классификации Базилевич, Панковой, 1968), то в 2012 как средняя при одном и том же хлоридносульфатном типе засоления.

Обратная картина наблюдалось за эти же годы в летний период. В засушливые месяцы 2011 года (июль - август) иона $\mathrm{Cl}^{-}$в том же слое 0-20 см, где сосредоточена основная масса корней, содержалось 2,30 мг.-экв./100г, а в 2012г.-в 1,6 раза меньше, соотношение $\mathrm{Cl}^{-}: \mathrm{SO}_{4}^{--}$- соответственно в 1,24 и 0,59 тип засоления слоя почвы $0-8$ см в первом случае характеризовался как сульфатно-хлоридный, во втором как хлоридносульфатный. Очевидно, увеличение содержания ионов $\mathrm{Cl}^{-}$и его соотношения к $\mathrm{S}_{4}^{--}$ 
способствовало резкому увеличению урожайности разнотравья и солянок в 2012 году. Особенно выделялся буйным ростом курай - солянка грузинская Salsola iberica Sennen. et Раи. В период с августа по октябрь в фитомассе встречались и другие представители солянок - солянка южная, петросимония супротиволистная, петросимония трехтычинковая, из сложноцветных - полыни таврическая и Лерха. Но доля курая в суммарной фитомассе была превалирующей - 53,6-68,1 ц/га. Надземная фитомасса солянок в 2012 году превысила показатель 2011 года в 20,1 раза. Такого обилия растений (6076 экз./ $\mathrm{M}^{2}$ ) Salsolai berica, такого интенсивного роста (до 1-1.2 м) и формирования фитомассы, как в 2012 году, ранее в рассматриваемых условиях не наблюдалось, хотя очаги встречались ежегодно на значительных площадях. Биологическая особенность этого растения, очевидно, такова, что засушливый период в апреле - мае (интеграл засушливости 37,3$)$ и последующая оптимизация условий увлажнения способствуют достижению высокой продуктивности растений.

Динамика экологических факторов и содержания вредных солей В гор А (0-8 см) и В 1 (9-20 см) светло-каштановой почвы за вегетационные периоды 2011-2013 годов.

\begin{tabular}{|c|c|c|c|c|c|c|c|c|c|c|c|c|c|c|c|c|c|c|}
\hline $\begin{array}{c}\text { Время } \\
\text { года, } \\
\text { слой } \\
\text { почвы }\end{array}$ & \multicolumn{6}{|c|}{$2011 r$. } & \multicolumn{6}{|c|}{$2012 r$. } & \multicolumn{6}{|c|}{$2013 r$. } \\
\hline \multirow{3}{*}{$\begin{array}{l}\text { Весна, } \\
\text { апрель } \\
\text {-май. }\end{array}$} & \multicolumn{6}{|c|}{$\begin{array}{c}1-85 \mathrm{MM} ; 2-13,8^{\circ} \mathrm{C} ; 3-73 \% ; 4135 \mathrm{MM} ; 5-0,30 ; \\
6 \mathrm{a}-15,7 \mathrm{u} / \mathrm{ra}^{*}\end{array}$} & \multicolumn{6}{|c|}{$\begin{array}{c}1-25 \text { MM; } 2-18,0^{\circ} \mathrm{C} ; 3-61 \% ; 4-202 \text { MM; } 5-0,06 ; \\
6 \mathrm{a}-1,7 \mathrm{n} / \mathrm{ra}\end{array}$} & \multicolumn{6}{|c|}{$\begin{array}{c}1-40 \mathrm{MM} ; 2-16,4^{0} \mathrm{C} ; 3-64 \% ; 4-178 \mathrm{MM} ; 5-0,10 \\
6 \mathrm{a}-10,7 \mathrm{n} / \mathrm{ra}\end{array}$} \\
\hline & \multirow{2}{*}{$\begin{array}{c}\text { сумма } \\
\text { солей* } \\
\text { * }_{\text {мг-- }} \\
\text { экв/10 } \\
\text { 0г }\end{array}$} & \multicolumn{3}{|c|}{ содержание ионов } & \multicolumn{2}{|c|}{ соотнотение } & \multirow{2}{*}{$\begin{array}{l}\text { сумм } \\
\text { a } \\
\text { солей }\end{array}$} & \multicolumn{3}{|c|}{ содержание ионов } & \multicolumn{2}{|c|}{ соотнотение } & \multirow[t]{2}{*}{$\begin{array}{l}\text { сумма } \\
\text { солей }\end{array}$} & \multicolumn{3}{|c|}{ содержание ионов } & \multicolumn{2}{|c|}{$\begin{array}{c}\text { соотношени } \\
\text { e }\end{array}$} \\
\hline & & $\mathrm{Cl}^{-}$ & $\mathrm{SO}_{4}^{-}$ & $\mathrm{Ca}^{++}$ & $\begin{array}{l}\mathrm{Cl}^{-}: \\
\mathrm{SO}_{4}^{-}\end{array}$ & $\begin{array}{l}\mathrm{Ca}^{++} \\
\pm \\
\mathrm{SO}_{4}^{-}\end{array}$ & & $\mathrm{Cl}^{-}$ & $\mathrm{SO}_{4}^{-}$ & $\mathrm{Ca}^{++}$ & $\mathrm{Cl}^{-}$ & $\begin{array}{l}\mathrm{Ca}^{++} \pm \\
\mathrm{SO}_{4}^{-}\end{array}$ & & $\mathrm{Cl}^{-}$ & $\mathrm{SO}_{4}^{-}$ & $\mathrm{Ca}^{++}$ & $\begin{array}{l}\mathrm{Cl}^{-}: \\
\mathrm{SO}_{4}^{-}\end{array}$ & $\begin{array}{l}\mathrm{Ca}^{++} \pm \\
\mathrm{SO}_{4}^{-}\end{array}$ \\
\hline \multirow[t]{2}{*}{$\begin{array}{c}0-8 \mathrm{~cm} \\
9-20 \mathrm{~cm}\end{array}$} & 0,06 & 0,21 & 1,50 & 0,50 & 0,14 & $-1,00$ & 0,31 & 0,82 & 1,62 & 0,56 & 0,51 & $-1,06$ & 0,26 & 0,39 & 1,38 & 0,55 & 0,28 & $-0,83$ \\
\hline & 0,13 & 0,30 & 0,85 & 0,50 & 0,35 & $-0,35$ & 0,47 & 0,88 & 1,77 & 0,59 & 0,50 & $-1,18$ & 0,33 & 0,37 & 1,48 & 0,59 & 0,25 & $-0,89$ \\
\hline $\begin{array}{l}\text { Лето, } \\
\text { июль- } \\
\text { август }\end{array}$ & \multicolumn{6}{|c|}{$\begin{array}{c}1-64 \mathrm{Mm} ; 2-27,4^{\circ} \mathrm{C} ; 3-58 \% ; 4-315 \mathrm{Mm} ; 5-0,11 ; \\
66-8,9 \mathrm{~m} / \mathrm{ra}\end{array}$} & \multicolumn{6}{|c|}{$\begin{array}{c}1-102 \mathrm{MM} ; 2-25,8^{8} \mathrm{C} ; 3-62 \% ; 4-275 \mathrm{MM} ; 5- \\
0,21 ; \\
66-68,5\end{array}$} & \multicolumn{6}{|c|}{$\begin{array}{c}1-83 \mathrm{Mm}_{2}, 2-25,0^{\circ} \mathrm{C} ; 3-59 \% ; 4-355 \mathrm{MM} ; 5-0,11 ; \\
66-36,3\end{array}$} \\
\hline & \multirow{2}{*}{$\begin{array}{c}\text { сумма } \\
\text { солей, } \\
\text { мт-- } \\
\text { экв/100г }\end{array}$} & \multicolumn{3}{|c|}{ содержание ионов } & \multicolumn{2}{|c|}{ соотнотение } & \multirow{2}{*}{$\begin{array}{l}\text { сумма } \\
\text { солей } \\
\mathrm{Ca}^{+}\end{array}$} & \multicolumn{3}{|c|}{$\begin{array}{c}\text { содержание } \\
\text { ионов }\end{array}$} & \multicolumn{2}{|c|}{ соотношенне } & \multirow[t]{2}{*}{$\begin{array}{l}\text { сумма } \\
\text { солей }\end{array}$} & \multicolumn{3}{|c|}{ содержание ионов } & \multicolumn{2}{|c|}{$\begin{array}{c}\text { соотнотенн } \\
\text { е }\end{array}$} \\
\hline \multirow{3}{*}{$\begin{array}{c}0-8 \mathrm{cM} \\
9-20 \mathrm{~cm}\end{array}$} & & $\mathrm{Cl}^{-}$ & $\mathrm{SO}_{4}^{-}$ & $\mathrm{Ca}^{++}$ & $\begin{array}{ll}\mathrm{Cl}^{-}: \\
\mathrm{SO}_{4}^{-}\end{array}$ & $\begin{array}{l}\mathrm{SO}_{4}^{-} \\
\pm \\
\mathrm{SO}_{4}^{-}\end{array}$ & & $\mathrm{Cl}^{-}$ & $\begin{array}{l}\text { SO } \\
4\end{array}$ & $\mathrm{Ca}_{+}^{+}$ & $\begin{array}{ll}\mathrm{Cl}^{-}: \\
\mathrm{SO}_{4}\end{array}$ & $\begin{array}{l}\mathrm{Ca}^{++} \pm \\
\mathrm{SO}_{4}^{-}\end{array}$ & & $\mathrm{Cl}^{-}$ & $\mathrm{SO}_{4}^{-}$ & $\mathrm{Ca}^{++}$ & $\begin{array}{l}\mathrm{Cl}: \\
\mathrm{SO}_{4}\end{array}$ & $\begin{array}{l}\mathrm{Ca}^{++} \pm \\
\mathrm{SO}_{4}^{-}\end{array}$ \\
\hline & 0,32 & 0,96 & 1,82 & 0,56 & 0,50 & $-1,26$ & 0,12 & 0,28 & $\begin{array}{c}0,8 \\
2\end{array}$ & 0,65 & 0,34 & $-0,17$ & 0,24 & 0,41 & 0,89 & 0,63 & 0,46 & $-0,26$ \\
\hline & 0,29 & 0,87 & 1,41 & 0,63 & 0,61 & $-0,78$ & 0,24 & 0,38 & $\begin{array}{c}0,8 \\
7\end{array}$ & 0,59 & 0,44 & $-0,28$ & 0,35 & 0,46 & 0,95 & 0,71 & 0,48 & $-0,24$ \\
\hline
\end{tabular}

Примечание. 1 - сумма осадков. Средние значения: 2 - температуры воздуха; 3 - относительной влажности воздуха; 4 - испаряемости; 5 - коэффициента увлажнения; 6а - урожайности фитомассы эфемеров и эфемероидов; 6б - урожайности фитомассы разнотравья и солянок.

Таблица 2

Коэффициент использования ФАР пастбищными фитоценозами на светло-каштановой почве Кочубейской биосферной станции, 2011-2013

\begin{tabular}{|c|c|c|c|}
\hline \multirow{2}{*}{ Год } & \multirow{2}{*}{ Всего } & \multicolumn{2}{|c|}{ Приходится на долю, \% } \\
\cline { 3 - 4 } & 0,20 & $\begin{array}{c}\text { эфемеров и } \\
\text { эфемероидов }\end{array}$ & разнотравья и солянок \\
\hline 2011 & 0,57 & 63,8 & 36,2 \\
\hline 2012 & 0,36 & 2,4 & 97,6 \\
\hline 2013 & 0,38 & 22,8 & 77,2 \\
\hline Средний & & 19,7 & 80,3 \\
\hline
\end{tabular}


Урожайность зеленой фитомассы во второй половине лета 2012 года увеличилась и за счет разнотравья, в первую очередь, из семейства сложноцветных - полыней таврической Artemisia taurica Willd. и Лерха Artemisia lercheana Web. et Stechm., из семейства маревых - петросимонии супротиволистной Petrosimonia oppositifolia (Pall.) Litv., петросимонии трехтычинковой Petrosimonia triandra (Pall.) Simonk., солянки южной Salsola australis R. Br., лебеды татарской Atriplex tatarica L., из семейства парнолистниковых - парнолистника обыкновенного Zygophyllum vulgaris L., из злаковых - житняка пустынного Agropyrondes ertorum (Fisch. et Link) Schult. и др.

Экологические условия функционирования экосистем в 2013 году занимают промежуточное положение между двумя предшествовавшими годами исследований. Это касается и климатических условий, и содержания солеобразующих ионов в почве, и урожайности фитомассы.

Увеличение или уменьшение урожайности надземной фитомассы $(x)$ сопровождается соответствующей динамикой корневой массы растений $(Y)$. Коррелятивная зависимость между этими показателями неодинакова в годы с различной влагообеспеченностью. Так, согласно нашим расчетам, в наиболее увлажненном 2011 году (301 мм осадков за вегетационный период) она выражается уравнением регрессии: $Y=3,37 x-25,54$ при $x=0,84$; в менее увлажненном (298 мм) 2012: $Y=0,238 x+46,45, x=0,51$; в засушливом (185 мм) 2013: $Y=10,16 x+37,35, x=0,17$. Таким образом, формирование фитомассы и ее видового состава в Терско-Кумской низменности Прикаспия является результатом совокупного действия различных экологических факторов, основными из которых являются: осадки, температура воздуха, ее относительная влажность, испаряемость, коэффициент увлажнения, а также степень и химизм засоления почвы. Эти зависимости выражаются следующими уравнениями множественной регрессии:

- для эфемеровой синузии: $\mathrm{Y}=17,13+0,0425 \mathrm{X}_{1}+0,0087 \mathrm{X}_{2}-4,66 \mathrm{X}_{3}-20,65 \mathrm{X}_{4}+$ $0,6 \mathrm{X}_{5}$, где $\mathrm{Y}$ - урожайность фитомассы, ц/га воздушно-сухой массы; $\mathrm{X}_{1}$ - осадки за вегетационный период; $\mathrm{X}_{2}$ - испаряемость, мм; $\mathrm{X}_{3}-\mathrm{KУ} ; \mathrm{X}_{4}-$ содержание $\mathrm{Cl}^{-}$в слое 0$20 \mathrm{~cm} ; \mathrm{X}_{5}-$ соотношение $\mathrm{Cl}^{-}: \mathrm{SO}_{4}{ }^{--}$в слое $0-20 \mathrm{~cm}$ ); $21,44 \mathrm{X}_{5}$

- для разнотравья и солянок: $\mathrm{Y}=9,65+0,18 \mathrm{X}_{1}-0,0147 \mathrm{X}_{2}-1,54 \mathrm{X}_{3}+45,78 \mathrm{X}_{4}-$

Для оценки эффективности использования пастбищным фитоценозом ФАР надо знать продолжительность его вегетационного периода и количество калорий, поступающих на поверхность почвы за этот период. По средним многолетним данным продолжительность вегетационного периода пастбищных фитоценозов в районе Кочубея составляет 260 дней (с 27 марта по 15 ноября). За годы проведения наших исследований даты перехода указанной температуры воздуха через $\pm 5^{\circ} \mathrm{C}$ в 2011 года пришлись на 15 марта и 2 ноября, в 2012 году на 24 марта и 30 ноября, в 2013 - на 1 марта и 27 ноября. Продолжительность вегетационного периода пастбищных экосистем составила соответственно по годам 232, 251 и 274 дня, количество ФАР, поступившей на $1 \mathrm{~cm}^{2}$ почвы за эти годы $-50,00,50,00$ и 52,96 ккал.

Коэффициенты использования ФАР пастбищными фитоценозами на светлокаштановой почве, которые рассчитаны нами с использованием этих данных для Кочубейской биосферной станции в 2011-2013 годах, приведены в таблице 2.

В зависимости от климатических условий года пастбищные фитоценозы используют 0,20-0,57 \% ФАР. Доля эфемеров и эфемероидов из этого количества составляет в среднем за годы исследований около $20 \%$, остальные $80 \%$ - разнотравье и солянки, основная часть из которых приходится на солянку грузинскую (курай) - представитель солянок, плохо поедаемый животными и менее ценный в кормовом отношении. 


\section{ЗАКЛЮЧЕНИЕ}

1. В условиях Терско-Кумской низменности наблюдается два пика продуктивности фитоценозов: первый - эфемеров и эфемероидов в середине мая - начале июля; второй - разнотравья и солянок во второй половине сентября.

2. Основными факторами достижения высокой продуктивности эфемеров и эфемероидов (в 2011 году 13-15 ц/га воздушно-сухой массы) на светло-каштановой почве Северо-Западного Прикаспия являются: осадки порядка 80-85 мм в течение апреля - мая при среднесуточной температуре воздуха $15-16{ }^{\circ} \mathrm{C}$, его относительной влажности 70 $73 \%$, испаряемости 130-140 мм, КУ 0,30, хлоридно-сульфатном типе засоления слабой степени в слое 0-35 см. Коэффициент использования ФАР только эфемеровой синузией в этом случае достигает $0,13 \%$, а всей фитомассой за вегетационный период $0,20 \%$.

Уменьшение количества осадков за тот же период до 25-26 мм, относительной влажности воздуха до $61 \%$, КУ до 0,06 при одновременном увеличении среднесуточной температуры воздуха до $18{ }^{\circ} \mathrm{C}$, испаряемости до 200-202 мм приводит к увеличению содержания ионов $\mathrm{Cl}^{-}$в том же слое почвы до 0,82-0,85 мг-экв, снижению урожайности фитомассы до 1,7 ц/га (2012). Коэффициент использования ФАР снижается до $0,01 \%$

3. В годы с обильными осадками в июле - августе (102 мм), несмотря на увеличение среднесуточных температур воздуха до $25-26^{\circ} \mathrm{C}$ и испаряемости до 275 мм, сохраняется относительно высокий КУ $(0,21)$, содержание $\mathrm{Cl}^{-}$в слое $0-20$ см снижается до 1,40 мг-экв./100 г, соотношение $\mathrm{Cl}^{-}: \mathrm{SO}_{4}^{--}$до $0,59-0,84$, а урожайность разнотравья и солянок (преимущественно солянки грузинской) увеличивается до 69,5 ц/га. Коэффициент использования ФАР достигает 0,57 , из которых на долю фитомассы разнотравья и солянки грузинской приходится 87,6 \% (2012).

4. В обычные по климатическим условиям годы (2013), когда атмосферные осадки в течение вегетационного периода распределяются относительно равномерно, урожайность эфемеров и эфемероидов составляет 10,7 ц/га, разнотравья и солянок 36,3 ц/га, коэффициент использования ФАР за вегетационный период достигает 0,36, доля эфемеровой синузии в нем - всего $22,6 \%$.

5. Увеличение количества осадков в летний период (июль - август) способствует доминированию менее ценной в кормовом отношении культуры - солянки грузинской. Задача дальнейших исследований заключается в том, чтобы оценить его фитомелиорирующую роль: вынос солеобразующих ионов из почвы и дальнейшее перераспределение их в экосистеме с учетом характера перемещения по территории этого «перекати поле».

\section{БИБЛИОГРАФИЧЕСКИЙ СПИСОК}

Базилевич Н.И., Панкова Е.И. 1968. Инструкция по учету засоленных почв. М.: Министерство мелиорации и водного хозяйства СССР, Почвенный институт им. В.В. Докучаева, Гипроводхоз. 50 с.

Гасанов Г.Н., Мусаев М.Р., Абдурахманов Г.М., Курбанов С.А., Аджиев А.М. 2004. Фитомелиорация засоленных почв Западного Прикаспия. М.: Наука. 270 с.

Гасанов Г.Н. 2008. Основы систем земледелия Западного Прикаспия. Махачкала. 263 с.

Джапова Р.Р. 2007. Динамика растительного покрова Ергененской возвышенности и Прикаспийской низменности в пределах Республики Калмыкия. Автореф. дис. ... д.б.н. М.: МГУ. 47 с.

Залибеков 3.Г. 2000. Процессы опустынивания и их влияние на почвенный покров. Махачкала. 219 с.

Каюмов М.К. 1977. Справочник по программированию урожаев. М.: Россельхозиздат. 188 с.

Муратчаева П.М.-С., Хабибов А.Д. 2008. О состоянии растительного покрова зимних пастбищ равнинного Дагестана в зависимости от режима использования. Современные наукоемкие технологии. 2: 92-93.

Ничипорович А.А. 1963. О путях повышения продуктивности фотосинтеза растений в посевах. $B$ кн.: Фотосинтез и вопросы продуктивности растений. М.: Изд-во АН ССР: 5-36.

Титлянова А.А. 1988. Продуктивность травяных экосистем. В кн.: Биологическая продуктивность травяных экосистем. Географические закономерности и экологические особенности. Новосибирск: Наука: $109-127$. 
Усманов Р.3. 2009. Экологическая оценка и научные основы восстановления природного потенциала деградированных почв Северо-Западного Прикаспия. Автореф. дис. ... д.б.н. Махачкала. 46 с.

Черепанов С.К. 1981. Сосудистые растения СССР. Л.: Наука. 510 с.

Walter H. D. 1964. Vegetation der Erde in oko-physiolohischen Betrachtung. Die tropicshen und subtropischen Zonen. Vol. 1. Jena: Veb Guster Fischer Verlag. 551 p.

\section{REFERENCES}

Bazilevich N.I., Pankova E.I. 1968. Instruktsiya po uchetu zasolennykh pochv [Instructions for accounting of saline soils]. Moscow: Ministry of Land Reclamation and Water Resources of the USSR, Soil Institute, Giprovodkhoz. 50 p. (in Russian).

Cherepanov S.K.1981. Sosudistye rasteniya SSSR [Vascular plants of the USSR]. Leningrad: Nauka. 510 p. (in Russian).

Dzhapova R.R. 2007. Dinamika rastitel'nogo pokrova Ergenenskoy vozvyshennosti i Prikaspiyskoy nizmennosti v predelakh Respubliki Kalmykiya [Dynamics of vegetation Ergenenskaya upland and the Caspian lowlands within the Republic of Kalmykia: SciD Abstract]. Moscow: Moscow State University. 47 p. (in Russian).

Hasanov G.N. 2008. Osnovy sistem zemledeliya Zapadnogo Prikaspiya [Bases of systems of agriculture of the Western Precaspian]. Makhachkala. 263 p. (in Russian).

Hasanov G.N., Musaev M.R, Abdurakhmanov G.M., Kurbanov S.A., Adzhiev A.M. 2004. Fitomelioratsiya zasolennykh pochv Zapadnogo Prikaspiya [Phytomelioration of saline soils of the Western Caspian]. Moscow: Nauka. 270 p. (in Russian).

Kayumov M.K.1977. Spravochnik po programmirovaniyu urozhaev [Programming Manual of harvests]. Moscow: Rossel'khozizdat. 188 p. (in Russian).

Muratchaeva P.M.-S., Habibov A.D. 2008. On the state of vegetation of winter pastures of Dagestan depending on usage. Sovremennye naukoemkie tekhnologii. 2: 92-93 (in Russian).

Nichiporovich A.A. 1963. Ways to improve the productivity of plant photosynthesis in crops. In: Fotosintez i voprosy produktivnosti rasteniy [Photosynthesis and plant productivity]. Moscow: Academy of Sciences of the USSR Publ.: 5-36 (in Russian).

Titlyanova A.A. 1988. Productivity of grassland ecosystems. In: Biologicheskaya produktivnost' travyanykh ekosistem. Geograficheskie zakonomernosti i ekologicheskie osobennosti [Biological productivity of grass ecosystems. Geographical patterns and ecological features]. Novosibirsk: Nauka: 109-127 (in Russian).

Usmanov R.Z. 2009. Ekologicheskaya otsenka i nauchnye osnovy vosstanovleniya prirodnogo potentsiala degradirovannykh pochv Severo-Zapadnogo Prikaspiya [Environmental assessment and scientific basis of the natural potential recovery of degraded soils of the North-West Caspian: SciD Abstract]. Makhachkala. 46 p. (in Russian).

Walter H. D. 1964. Vegetation der Erde in oko-physiolohischen Betrachtung. Die tropicshen und subtropischen Zonen. Vol. 1. Jena: Veb Guster Fischer Verlag. 551 p.

Zalibekov Z.G. 2000. Protsessy opustynivaniya i ikh vliyanie na pochvennyy pokrov [Desertification processes and their impact on soil]. Makhachkala. 219 p. (in Russian). 